\title{
The immunobiology of primary sclerosing cholangitis
}

\author{
Jonathan H. Aron • Christopher L. Bowlus
}

Received: 4 May 2009/Accepted: 6 May 2009/Published online: 26 May 2009

(C) The Author(s) 2009. This article is published with open access at Springerlink.com

\begin{abstract}
Primary sclerosing cholangitis (PSC) is a chronic cholestatic liver disease histologically characterized by the presence of intrahepatic and/or extrahepatic biliary duct concentric, obliterative fibrosis, eventually leading to cirrhosis. Approximately $75 \%$ of patients with PSC have inflammatory bowel disease. The male predominance of PSC, the lack of a defined, pathogenic autoantigen, and the potential role of the innate immune system suggest that it may be due to dysregulation of immunity rather than a classic autoimmune disease. However, PSC is associated with several classic autoimmune diseases, and the strongest genetic link to PSC identified to date is with the human leukocyte antigen $D R B 01^{*} 03$ haplotype. The precise immunopathogenesis of PSC is largely unknown but likely involves activation of the innate immune system by bacterial components delivered to the liver via the portal vein. Induction of adhesion molecules and chemokines leads to the recruitment of intestinal lymphocytes. Bile duct injury results from the sustained inflammation and production of inflammatory cytokines. Biliary strictures may cause further damage as a result of bile stasis and recurrent secondary bacterial cholangitis. Currently, there is no effective therapy for PSC and developing a rational therapeutic strategy demands a better understanding of the disease.
\end{abstract}

\footnotetext{
J. H. Aron

Department of Internal Medicine,

University of California Davis Medical Center,

4150 V Street, PSSB 3100,

Sacramento, CA 95817, USA

C. L. Bowlus $(\bowtie)$

Division of Gastroenterology and Hepatology,

University of California Davis Medical Center,

4150 V Street, PSSB 3500, Sacramento, CA 95817, USA

e-mail: clbowlus@ucdavis.edu
}

Keywords Primary sclerosing cholangitis .

Biliary cirrhosis · Pathogenesis - Inflammatory bowel disease

$\begin{array}{ll}\text { Abbreviations } & \\ \text { PSC } & \text { Primary sclerosing cholangitis } \\ \text { IBD } & \text { Inflammatory bowel disease } \\ \text { HLA } & \text { Human leukocyte antigen } \\ \text { UC } & \text { Ulcerative colitis } \\ \text { Mdr2 } & \text { Multidrug resistance-2 } \\ \text { VCAM-1 } & \text { Vascular cellular adhesion molecule-1 } \\ \text { PG-PS } & \text { Peptidoglycan-polysaccharide } \\ \text { DNBS } & \text { Dinitrobenezenesulfonic acid } \\ \text { TNBS } & \text { Trinitrobenzene sulfonic acid } \\ \text { DSS } & \text { Dextran sulfate sodium } \\ \alpha \text {-GalCer } & \alpha \text {-Galactosylceramide } \\ \text { NK } & \text { Natural killer } \\ \text { KIRs } & \text { Killer immunoglobulin-like receptors } \\ \text { ITIMs } & \text { Immunoreceptor tyrosine-based inhibitory } \\ & \text { motifs } \\ \text { ITAMs } & \text { Immunoreceptor tyrosine-based activating } \\ & \text { motifs } \\ \text { MIC } & \text { Major histocompatibility complex class I } \\ & \text { chain-related } \\ \text { CCR5 } & \text { CC-type chemokine receptor 5 } \\ \text { TCR } & \text { T-cell receptor } \\ \text { MAdCAM-1 } & \text { Mucosal adressin cell adhesion molecule-1 } \\ \text { CLA } & \text { Cutaneous lymphocyte antigen } \\ \text { AIH } & \text { Autoimmune hepatitis } \\ \text { PBC } & \text { Primary biliary cirrhosis } \\ \text { LIL } & \text { Liver-infiltrating lymphocytes } \\ \text { VAP-1 } & \text { Vascular adhesion protein-1 } \\ \text { HEV } & \text { High endothelial venules } \\ \text { TGF } & \text { Transforming growth factor } \\ \text { NOS2 } & \text { Nitric oxide synthase 2 } \\ \text { p-ANCA } & \text { Perinuclear anti-neutrophil antibodies } \\ & \end{array}$




$\begin{array}{ll}\text { BPI } & \text { Bactericidal/permeability increasing } \\ \text { BEC } & \text { Biliary epithelial cells } \\ \text { PAMPs } & \text { Pathogen-associated molecular patterns } \\ \text { LPS } & \text { Lipopolysaccharide } \\ \text { TLRs } & \text { Toll-like receptors }\end{array}$

\section{Introduction}

Primary sclerosing cholangitis (PSC) is a chronic cholestatic liver disease characterized by concentric and obliterative fibrosis of the intrahepatic and/or extrahepatic bile ducts and a lymphocytic portal tract inflammation leading to cholestasis, cholangitis, and cirrhosis $[1,2]$. In addition to liver disease, $75-90 \%$ of PSC patients have either a history of or co-existent inflammatory bowel disease (IBD), primarily ulcerative colitis (UC) [2,3]. Interestingly, unlike IBD which has a slight female predominance, PSC has a 2:1 male predominance. Although the disease may affect children and older adults, the median age of onset is in the fourth decade [4]. The natural history of the disease is quite variable with an average time from diagnosis to death or liver transplant of 12 to 15 years. In addition to cirrhosis, approximately $10-15 \%$ of PSC patients will develop cholangiocarcinoma during their lifetime [3]. Short of liver transplantation, no therapy has been shown to alter the natural history of PSC. Herein we review the current understanding of the immunobiology of PSC with particular attention to the epidemiologic, genetic, and functional characteristics of this disease.

\section{Epidemiology}

Epidemiologic studies of PSC are challenging because the disease is rare, often requires specialized expertise, and until recently, could only be diagnosed by invasive procedures. Therefore, population-based studies likely underestimate the true prevalence and incidence of PSC. Nevertheless, the incidence (0.9-1.3 per 100,000/year) and prevalence $(8.5-14.2$ per 100,000$)$ of PSC have been reported to be similar in Oslo, Norway, Wales, and Olmstead County, Minnesota [5-8]. However, in the largest study published to date, the incidence and prevalence were considerably lower in a general medical practice database of the UK [9]. There appears to be a lower prevalence in Southern Europe, Asia, and Alaska [10-12].

While the male to female predominance of 2:1 for PSC has been largely reported, a study from Turkey reported that $15 / 16$ PSC patients in their series were women [13] and a Canadian study reported a slight male predominance that did not reach statistical significance, with an age-adjusted incidence rate of 1.01 per 100,000 person-years for men versus 0.84 per 100,000 person-years for women [8]. Age at diagnosis has also varied by geographic region. While the majority of patients have been reported to be diagnosed in their thirties [14], studies from Japan note a bimodal age distribution with most diagnoses occurring in the third decade and a second peak in the seventh decade of life. Within this distribution, younger patients were more likely to have IBD than older patients and older patients were more likely to have autoimmune pancreatitis and cholangiocarcinoma $[15,16]$. The average age of patients diagnosed with cholangiocarcinoma in the Japan study was 58. The overall incidence of cholangiocarcinoma reported in this population was $3.6 \%$, much lower than the $10-15 \%$ that has been reported in previous studies $[3,15]$.

The strength of the association of PSC with IBD also differs by geographic origin. Approximately $80 \%$ of PSC patients from northern Europe and the USA have concomitant IBD [17-20], while only 50\% from Southern Europe $[12,21]$ and $35 \%$ from Asia have IBD [11, 22, 23]. The majority of PSC patients with IBD have ulcerative colitis although Kaplan et al. reported that $38.8 \%$ of patients with PSC in Canada have Crohn's disease versus only 5.7$13.6 \%$ reported in other studies [8]. To explain this discrepancy, they noted that the prevalence of $\mathrm{CD}$ in Alberta was 1.5 times the prevalence of UC, whereas UC is more prevalent than $\mathrm{CD}$ in the rest of the world. They hypothesized that the increased rates of $\mathrm{CD}$ seen among PSC patients may reflect an unexplained occurrence of rising incidence of $\mathrm{CD}$ in Canada and worldwide [8]. Alternatively, the IBD associated with PSC often shares features with both UC and CD [24].

\section{Immunopathogenesis of PSC}

The association of PSC with IBD suggests that like the latter, PSC is not necessarily a classic autoimmune disease in the sense that there is targeted destruction of tissue directed at a specific self-antigen. Rather, IBD is the result of an abnormal innate immune response to antigens of the intestinal flora, which activates an adaptive immune response [25]. Genome-wide association studies and subsequent functional studies have implicated several genes such as NOD2 and $A T G 16 L 1$, both involved in the intracellular processing of bacterial antigens [26-28]. In the case of $\mathrm{CD}$, this leads to a predominantly $\mathrm{T}_{\mathrm{H}^{-1}}$ type of immune response and increases in IL-17-producing lymphocytes. In contrast, ulcerative colitis tends to be more of a $\mathrm{T}_{\mathrm{H}}-2$ response. Whether PSC, which tends to be characterized by $\mathrm{T}_{\mathrm{H}^{-}} 1$ cytokines and stricturing reminiscent of $\mathrm{CD}$, involves similar mechanisms has not been fully 
investigated. Further complicating the matter is the association of PSC with (1) classic autoimmune diseases such as type I diabetes, thyroid disease, rheumatoid arthritis, and others; (2) the human leukocyte antigen (HLA)DRB1*0301 haplotype; and (3) autoantigens to neutrophils and biliary epithelial cells.

Several working models have been proposed to explain many of the peculiar features of PSC, namely, the strong association with IBD, the observation that PSC may develop after total colectomy and that the liver disease activity of PSC does not correlate with the intestinal disease activity of IBD [1, 29]. In fact, IBD is often quiescent even in the most severe cases of PSC. Notably, the IBD associated with PSC, whether classified as UC or CD, almost invariably affects the entire colon. In addition, rectal sparing and involvement of the ileum are more common in UC patients with PSC compared to those without PSC (58\% and $51 \%$ versus $6 \%$ and $7 \%$, respectively) [24].

Although hypotheses related to the etiology of PSC have been generated and several lines of evidence support various aspects of each model, a unifying hypothesis remains to be proposed. Vierling proposed that the immunopathogenesis of PSC involves multiple steps starting with the activation of a cholangiocyte by a bacterial pathogen that translocates to the liver from the gut [30]. Over time, there is chronic inflammation, periductal fibrosis, and ischemic atrophy of biliary epithelia leading to cholestasis, obstructive strictures, and eventually biliary cirrhosis [31].

The second hypothesis addresses how intestinal mucosal lymphocytes home to the liver. This theory suggests that lymphocytes are activated in the bowel of IBD patients and then aberrantly recruited to extraintestinal sites. The prodigious work of Adams et al. supports their hypothesis that a network of adhesion molecules and chemokine receptors that are normally restricted to the gut are aberrantly expressed in the liver leading to the recruitment of intestinal lymphocytes through the enterohepatic circulation [32-37]. However, the mechanisms leading to the aberrant expression of adhesion molecules and chemokines in the liver or even if they are dependent upon liver or intestinal factors remain unknown.

A third theory recently introduced by Fickert et al. compares the pathogenesis of PSC to arteriosclerosis [38]. Bile acids which can induce apoptosis and necrosis of cholangiocytes are normally excreted in mixed micelles with phospholipids and cholesterol to protect cholangiocytes. In the multidrug resistance knockout mouse (Mdr2-/-) which develops a PSC-like liver pathology (discussed in detail below), absence of phospholipids as a consequence of the $M d r 2$ defects results in bile acid toxicity and also in cholesterol-supersaturated bile, which could facilitate oxidation similar to the process of atherosclerosis.
In addition, cholangiocytes from $M d r 2-/-$ mice express cell adhesion molecules such as vascular cellular adhesion molecule-1. Further similarities in chemokines, growth factors, and cytokines support some commonality between atherosclerosis and PSC. However, support for this theory of toxic bile from humans is lacking. Genetic studies of the human ortholog of Mdr2 (MDR3) have not found any association of genetic variants with PSC susceptibility, and in PSC patients with a normal bilirubin, biliary secretion of bile acids and lipids has previously been shown to be normal [39-41].

\section{Animal models of PSC}

Given the abundance and variety of animal models from rodents to primates with spontaneous and induced inflammatory bowel diseases, it is surprising that none of these animal models have been reported to recapitulate all of the features of PSC (Table 1). Whether there is a unique characteristic of the human liver that is not shared by these model organisms or there has been a lack of systematic phenotyping of IBD models is unclear.

In addition to colitis, an ideal animal model of PSC would include histologic evidence of fibrous obliterative cholangitis and cholangiographic evidence of both intraand extrahepatic duct involvement. Animal models described to date include those involving bacterial cell wall components or colitis; those induced by injury to biliary epithelial cells or endothelial cells of hepatic arterioles or peribiliary capillaries; and those induced by toxic, infectious, or intraluminal injury of the biliary tract [42].

\section{Bacterial components}

A potential link between bacterial components and hepatobiliary inflammation was first substantiated by Chadwick and colleagues who demonstrated that $\mathrm{N}$-formylated chemotactic peptides that are produced by several species of intestinal bacteria undergo enterohepatic circulation and that the level of these compounds is increased in experimental colitis [43-45]. In addition, rectal administration of $N$-formyl L-methionine L-leucine L-tyrosine in rats with acetate-induced colitis results in a biliary-based inflammation consisting of macrophages and neutrophils in the early stages and subsequently $\mathrm{CD} 4+$ and $\mathrm{CD} 8+\mathrm{T}$ cells $[46,47]$.

In a series of experiments with surgically created selffilling jejunal blind loops leading to bacterial overgrowth, Lichtman and colleagues demonstrated that in genetically susceptible rat strains hepatobiliary injury with features similar to PSC develops including bile duct proliferation, fibrosis, and acute and chronic periportal and focal 
Table 1 Animal models of primary sclerosing cholangitis

\begin{tabular}{|c|c|c|c|c|}
\hline Animal & Treatment & IBD & Portal Inflammation & Biliary strictures \\
\hline Rat [47] & $\begin{array}{l}N \text {-formyl L-methionine } \\
\text { L-leucine L-tyrosine }\end{array}$ & $\begin{array}{l}\text { Yes } \\
\text { (acetate-induced) }\end{array}$ & $\begin{array}{l}\text { Macrophages/neutrophils } \\
\text { (early) T cells (late) }\end{array}$ & Unknown \\
\hline Rat $[48-50,133]$ & Self-filling jejunal blind loops & No & Yes & Fibrosis, strictures not documented \\
\hline CD-1 mouse [55] & Dextran sulfate sodium & Yes & Yes & Unknown \\
\hline$C f t r-/-[57]$ & Dextran sulfate sodium & Yes & Yes & Unknown \\
\hline SAMP1/YitFc [58] & None & Yes & Yes & Unknown \\
\hline$M d r 2-/-[59]$ & None & No & Yes & Yes \\
\hline
\end{tabular}

parenchymal inflammation [48]. The lack of similar findings in self-emptying blind loops that do not develop bacterial overgrowth suggested a role for bacteria or their cell wall components. The role of bacterial peptidoglycans was supported when the effects of the blind loops were abrogated by oral metronidazole and tetracycline or by mutanolysin, a muralytic enzyme which cleaves the beta 1$4 \mathrm{~N}$-acetylmuramyl- $\mathrm{N}$-acetylglucosamine linkage of peptidoglycan-polysaccharide $[49,50]$. These studies along with human studies suggesting an increase in intestinal permeability in IBD make plausible a theory of PSC involving the translocation of bacterial cell wall components via the portal circulation to the liver and inducing hepatobiliary inflammation and injury presumably through a pathway that initially involves activation of the innate immune response. However, this model does not have colitis and there is no evidence that bacterial overgrowth in humans leads to PSC. In fact, Bjornsson et al. concluded that small intestinal bacterial overgrowth and increased intestinal permeability are not important in the pathogenesis of chronic PSC based on their results that only one of 22 PSC patients had small intestine bacterial overgrowth and intestinal permeability of their patients did not differ significantly from that of controls [51].

Induced colitis

Several models of spontaneous and induced colitis have been studied to determine the pathologic basis of the association between colitis and PSC. Intrarectal instillation of 2,4-dinitrobenezenesulfonic acid (DNBS) consistently results in colitis in rodents, but there is no evidence of liver injury in this model. In C57BL/6 mice, DNBS treatment has led to P-selectin-dependent recruitment of lymphocytes to post-sinusoidal venules, but this was transient and not associated with an increase in liver enzymes [52]. In IL-10deficient mice that are prone to spontaneous colitis, DNBS treatment resulted in elevation of ALT and bilirubin which was significantly greater compared to wild-type mice but this was not associated with any histologic evidence of inflammation [53]. Trinitrobenzene sulfonic acid (TNBS)induced colitis, which is more similar to Crohn's disease, has failed to result in elevation of liver enzymes or demonstrate any histologic abnormality in the liver [54].

Despite a lack of liver inflammation in these models, the permeability of hepatocyte tight junctions is increased by both DNBS- and TNBS-induced colitis, the former being enhanced by IL-10 deficiency [53, 54]. This is not a direct effect of these agents on the liver as endoportal injection of TNBS does not cause changes in tight junction permeability [54]. These findings leave open the possibility that alteration of hepatocyte tight junctions in response to intestinal inflammation leads to passage of intestinal antigens or bacterial components from the sinusoid across the tight junction and into the canilicular space leading to macrophage and neutrophil recruitment, bile duct inflammation, and injury.

In contrast to DNBS and TNBS, colitis induced in CD-1 mice by dextran sulfate sodium (DSS) in drinking water is associated with histologic changes including cell infiltration around bile duct and focal necrosis [55]. Interestingly, in this model, cholangitis appeared to follow the development of colitis. After 14 days of DSS treatment, nearly all animals developed colitis whereas fewer than $10 \%$ developed liver inflammation and only $1 / 3$ of mice developed cholangitis after 28 days. However, even prior to histologic changes, there was an increase in the $\mathrm{CD} 4 / \mathrm{CD} 8$ ratio of liver lymphocytes, and analysis of mononuclear cell function revealed high levels of interferon- $\gamma$ production in contrast to IL-4 and IL-10. In addition, repeated injections of $\alpha$-galactosylceramide, a ligand for natural killer T (NKT) cells, ameliorated the liver inflammation but had no effect on the colitis [56]. The improvement in liver histology was accompanied by changes in liver mononuclear cells including a reduced $\mathrm{CD} 4 / \mathrm{CD} 8$ ratio, reduced percentages of NKT and natural killer (NK) cells, decreased interferon$\gamma$ production, and increased IL-4 production. Although this model provides an interesting opportunity to examine the 
link between colitis and liver inflammation, it has not been demonstrated to develop bile duct damage or fibrosis.

Given the similarities between PSC and the biliary disease associated with cystic fibrosis, Freedman et al. have investigated the possible role of the gene responsible for cystic fibrosis (cftr) in PSC. They demonstrated that while $c f t r-/-$ mice have normal liver histology, DSStreated $c f t r-/-$ mice not only develop colitis but also increased serum alkaline phosphatase and inflammation around the portal tracts including bile duct infiltration by mononuclear cells and bile duct proliferation [57].

Spontaneous models of colitis

SAMP1/YitFc mice develop spontaneous ileitis and have been reported to develop inflammation around intrahepatic and extrahepatic bile ducts [58]. Although expression of the chemokine CCL25 which has been associated with human PSC was not identified in the liver of these mice, further characterization of the liver disease in this model is awaited.

\section{Genetically altered models}

One of the more recent mouse models of PSC is the multidrug resistance gene $(M d r 2)$ knockout mouse. Targeted disruption of $M d r 2$ leads to sclerosing of the biliary tree in mice. Mdr2-/- mice develop extra- and intrahepatic biliary strictures and dilations, onion skin-type periductal fibrosis, and focal obliteration of bile ducts similar to that seen with primary and secondary sclerosing cholangitis in humans. Presumably, biliary phospholipids that are normally transported into bile via the canalicular phospholipids flippase Mdr2 and form mixed phospholipid-bile acid micelles protect cholangiocytes from bile acid-induced cell injury. Biliary phospholipids are absent in $M d r 2-/-$ which may lead to toxic bile acid-induced damage resulting in sclerosing cholangitis [59]. The portal inflammation in $M d r 2^{-1-}$ is unlikely to be of infectious origin as no bacterial translocation has been found in these animals, and bacterial counts and cultures are not different from controls [59]. However, unlike human PSC, the Mdr2-/do not develop IBD [38]. Like the $C f t r-/-$ mice, this model points to the potential role of hepatobiliary transporters and changes of bile composition in the pathogenesis of PSC [60].

\section{Genetic factors predisposing to PSC}

There is more than an 80-fold increased risk of PSC among first degree relatives suggesting a genetic link to the etiology of PSC [4]. Bergquist et al. reported that among a national Swedish cohort of PSC patients $(n=678)$, the risk of cholangitis was increased in offspring, siblings, and parents of the PSC patients, compared with relatives of a control group with hazard ratios of 11.5, 11.1, and 2.3, respectively [61]. Despite this strong genetic risk, the precise genes underlying this susceptibility have not been identified. Candidate genes ranging from mediators of fibrosis to bile acid transporters as well as immune-related genes have been reported. In most cases, the studies are underpowered, and with the exception of the human leukocyte antigen, the results have failed to be replicated in additional cohorts. A comprehensive accounting of the genetics of PSC is beyond the scope of this review. Rather, we will highlight those genetic studies that give insight into the immunopathogenesis of PSC.

\section{HLA and related gene associations}

Like many autoimmune diseases, an association with the HLA complex on chromosome 6p21 with PSC has been well documented. The initial reports of an HLA association with PSC came over 20 years ago from Norway and the UK when Schrumpf et al. and Chapman et al. reported a greater prevalence of the HLA class I allele B8 in PSC patients compared to controls $[62,63]$. Although similar frequencies of HLA-B8 have been reported in PSC patients from Finland and Australia, no associations with HLA-B8 or other HLA-B alleles were identified when studied in PSC populations from Italy or Brazil [64-67].

The initial report of an association between PSC and HLA class II genes utilized serologic methods and identified DR3 and DR52a as susceptibility markers. The first study from Norway reported that $70 \%$ of PSC patients with UC carried the HLA-DR3 antigen [62]. Subsequently, all 29 PSC patients who underwent liver transplant at UCLA were remarkably reported to be DR52a-positive [68]; however, this report was later retracted [69]. Soon after, molecular typing suggested that at least two susceptibility alleles are encoded in the class II HLA, specifically $D R B 1^{*} 0301$ (DR3) and $D R B 1 * 13$ (DR6), which are associated with the haplotypes defined by $D R B 1 * 0301$, $D Q A 1 * 0501, D Q B 1 * 0201$, and $D R B 1 * 13, D Q A 1 * 0103$, $D Q B 1 * 0603[70,71]$. In fact, approximately half of all PSC patients in Norway and Sweden carry at least one of these two haplotypes compared to less than $20 \%$ of the general population. It is important to note, however, that these haplotype associations were not seen in PSC patients from Italy and of the two, only the association with $D R B 1 * 13, D Q A 1 * 0103, D Q B 1 * 0603$ was present in PSC patients from Brazil $[64,65,71]$. In contrast, the $D R B 1 * 04$, $D Q A 1 * 03, D Q B 1^{*} 0302$ haplotype (DR4) has been associated with a protective effect in Scandinavia and the UK. Because of the strong linkage disequilibrium within the HLA 
region, identifying the gene or genes that account for the associations with these haplotypes has been problematic.

In addition to HLA associations, combinations of HLA class I alleles and killer immunoglobulin-like receptors (KIRs) have been found to affect susceptibility to autoimmune disease and infection. NK cell effector function is balanced by inhibitory and activating receptors [72]. A key set of NK receptors is KIR which bind HLA class I molecules. At least 14 functional KIR genes are present on chromosome 19q13.4 where they exhibit significant allelic and haplotypic variability, the latter of which is largely related to the presence or absence of activating KIR genes. Inhibitory KIRs encode immunoreceptor tyrosine-based inhibitory motifs in their cytoplasmic tails. Activating KIRs interact with DAP12 homodimers that contain immunoreceptor tyrosine-based activating motifs. Genetic studies implicate specific combinations of HLA and KIR alleles in autoimmunity, tumor immunosurveillance, and viral diseases. Combinations expected to increase activation of NK cells are associated with autoimmunity [73], slow progression of human immunodeficiency virus [74], and protection against hepatocellular carcinoma in hepatitis $\mathrm{C}$ virus (HCV) infection [75]. In contrast, the combination of HLA-CAsn80 (HLA-C1) and KIR2DL3 has been associated with clearance of $\mathrm{HCV}$ [76]. Karlsen et al. investigated the possible interaction between HLA class I alleles and KIR genes in 365 Scandinavian PSC patients and 368 healthy controls [77]. The frequency of HLA-Bw4 and HLA-C2, ligands for the inhibitory KIRs 3DL1 and 2DL1, respectively, was significantly reduced in PSC patients compared with controls suggesting an increase in NK cell activity by decreased inhibition.

In addition to the decreased suppression of $\mathrm{NK}$ cell activity through HLA-KIR interactions, genetic evidence suggests a possible role for the direct activation of NK cells through the major histocompatibility complex class I chainrelated (MIC) genes. $M I C A$ and $M I C B$ are encoded with the HLA region and their proteins activate NKG2D receptors on NK cells. Norris et al. found a strong protective effect of the $M I C A^{*} 002$ allele with an allele frequency of 0.180 in controls compared to 0.032 and 0.0 in two independently collected cohorts of PSC cases [78]. In contrast, the $M I C A^{*} 008$ allele frequency was increased in both sets of cases (0.66 in both) compared to controls (0.48). Although the $M I C A^{*} 008$ allele is part of the $B 8-D R 3$ haplotype, the association was also observed when the $M I C A^{*} 008$ allele was on a $B 7-D R 15$ haplotype. In contrast to these UK cohorts, a study of 130 Norwegian PSC patients and 306 healthy controls found associations with the MICA5.1 and MICB24 alleles [79]. However, these alleles are also found on the extended B8-MICA5.1-MICB24-DR3 haplotype and are not independent of HLA-B8 or DR3. Attempts at further dissection of the HLA region have only extended the HLA-DR3-associated haplotype more telomerically
[80]. Future efforts with larger patient cohorts and more densely spaced markers may eventually lead to the identification of the causative variant or variants, but the strong linkage disequilibrium of the region may prove to be an insurmountable barrier.

\section{Candidate genes}

With the strong association between PSC and UC, it would not be surprising to find that they shared some common genetic basis. However, this has not proven to be the case so far. Unlike PSC, the association between UC and HLA has been weak and inconsistent. Most consistent in UC are the positive associations with the $D R B 1^{*} 0103$ and $D R B 1 * 1502$ alleles, and a negative association with $D R B 1^{*} 0401$. In a direct comparison of 365 Scandinavian PSC patients, 330 Norwegian ulcerative colitis patients, and 368 healthy controls, Karlsen et al. concluded that HLA associations in PSC were of greater impact and mostly distinct from those in UC [81]. Similarly, studies comparing IBD susceptibility genes in PSC and IBD cohorts have failed to show any common genetic links including studies of NOD2/CARD15, TLR-4, CARD4, SLC22A4, SLC22A5, DLG5, and MDR1 [82, 83].

In addition to HLA alleles, ICAM-1 gene polymorphisms have been implicated in UC as well as a number of other inflammatory disorders including multiple sclerosis and Behcet's disease. ICAM-1 mediates leukocyte adhesion during immune responses and is important in transendothelial migration of neutrophils and T-cell activation. Previous studies have demonstrated expression of ICAM on proliferating bile ductules and interlobular bile ducts in PSC patients with advanced disease. The polymorphism K469E in exon 6 leads to a change from glutamic acid to lysine in the Ig-like domain 5 of ICAM-1 which is thought to affect interactions between LFA-1 and B cells. Yang et al. reported that in 104 PSC patients and 213 healthy controls from the UK the E/E frequency of the K469E polymorphism was significantly lower in PSC than in the control population (12\% versus $24 \%$, OR 0.41) [84]. However, a larger study of a Scandinavian PSC cohort was not able to reproduce these findings [85].

CC-type chemokine receptor 5 (CCR5) is a cell surface receptor expressed on $\mathrm{T}$ cells and macrophages which is activated by several chemokines, including RANTES, MIP1a, and MIP1b. A 32-base pair deletion (CCR5- $\Delta 32$ ) in the CCR5 gene leads to a frame shift and encodes a nonfunctioning receptor. Studies in several population have reported associations of PSC with the $\Delta 32$ polymorphism [86-89]. However, two studies showed a protective effect of the allele, while two others suggested that the allele increased susceptibility. Still, the largest study found no association at all [90]. 


\section{Cellular immune response in PSC}

Teasing out the causative immune response of PSC from the reactive responses to cholangitis, inflammatory bowel disease, and cirrhosis has been a major obstacle in the understanding of PSC. Although the inflammatory infiltrate of PSC is largely comprised of $\mathrm{T}$ cells, other cell types including NK cells, macrophages, B cells, and biliary epithelial cells are likely to play important roles in the immunopathogenesis of PSC (Fig. 1).

\section{Innate immune responses}

The activation of the innate immune system as a primary inciting event of PSC has been proposed by several investigators [31]. According to this theory, PSC is triggered by bacteria or more likely, pathogen-associated molecular patterns (PAMPs) such as lipopolysaccharide (LPS), lipoteichoic acid, peptidoglycans, and unmethylated bacterial dinucleotide motifs that enter the portal circulation through an inflamed permeable intestine. PAMPs activate macrophages, dendritic cells, and NK cells through pattern recognition receptors, including Tolllike receptors (TLRs) and CD14 leading to the secretion of cytokines which in turn activate NK cells (IL-12) and promote recruitment and activation of lymphocytes (TNF$\alpha$, IL-1 $\beta$, and CXCL8). NK cells may also be activated by MHC Class I chain-related gene products MICA and $\mathrm{MICB}$, which are stress-induced proteins that can promote



Fig. 1 Proposed mechanism for the immunopathogenesis of primary sclerosing cholangitis. Prior to the development of PSC, intestinal lymphocytes are activated in gut-associated lymph tissue and primed by dendritic cells to express $\alpha 4 \beta 7$ and CCR9 which result in the homing of these cells to MAdCAM-1 and CCL25, respectively. Normally, the expression of MAdCAM-1 and CCL25 is restricted to the gut, but in PSC, MADCAM-1 is found on portal vein endothelium and CCL25 on periportal sinusoidal endothelium. Although it has yet to be defined where lymphocytes enter the liver (portal venules, sinusoids, or post-sinusoidal capillaries), the expression of MAdCAM-1 and CCL25 leads to the recruitment of CD $44+\alpha 4 \beta 7+$ CCR9+ memory cells from the gut. The mechanisms leading to the expression of MAdCAM-1 and CCL25 in the liver are unknown but the latter appears to be PSC-specific. In addition, the recurrence of PSC after liver transplantation suggests that this is not an aberrant property inherent in the PSC liver. Induction of MAdCAM-1 and CCL25 may be in response to pathogen-associated molecular patterns $(P A M P S)$ that enter the liver from the gut via the portal vein or sinusoids and bind Toll-like receptors $(T L R s)$ on macrophages (Kuppfer cells, KC) and dendritic cells. Activation of these cells leads to the secretion of inflammatory cytokines which have been shown to induce MAdCAM-1 expression on hepatic endothelial cells. The reported enrichment of $\alpha E \beta 7$ lymphocytes in the PSC has been suggested to result from a transition of $\alpha 4 \beta 7+$ to $\alpha \mathrm{E} \beta 7+$ induced by transforming growth factor- $\beta$ (TGF- $\beta)$. The localization of lymphocytes to the biliary epithelium is poorly understood. Biliary epithelial cells $(B E C)$ can express a variety of cytokines and chemokines as well as MHC class I and II, CD44, and TLRs. LPS, a potent TLR-4 ligand, induces CCL 28 production by BEC leading to the recruitment of $\alpha 4 \beta 1+$ CCR $10+$ regulatory T cells (Treg). However, this phenomenon is seen in a variety of inflammatory liver diseases and is not specific for PSC. We should also note that while TLRs are present on BEC, they are localized to the apical membrane and likely only have contact with PAMPs in the case of ascending cholangitis. Anti-BEC antibodies have been detected in PSC patients and stimulate the production of several cytokines by BEC that could lead to localized recruitment of inflammatory cells 
the cytotoxic function of NK, NKT, and $\gamma \delta$ T cells through the NKG2D receptor.

Similar to the intestinal mucosa, the biliary mucosa expresses multiple TLRs and their expression has been shown to be induced in a variety of liver diseases [91]. Interestingly, IgG directed against biliary epithelial cells (BEC) has been found in the sera of some PSC patients. These sera induce the expression of TLR4 and TLR9 on BEC in culture and can be found to co-localize with these same TLRs on BEC in situ [92]. In fact, treatment of BEC with PSC sera containing anti-BEC antibodies induces secretion of GM-CSF, IL-1 $\beta$, and IL-8, which in turn may lead to the recruitment of neutrophils, macrophages, and $\mathrm{T}$ cells.

However, the targets of these anti-BEC antibodies remain unknown and other evidence that innate immune responses are dysregulated in PSC is largely circumstantial. Histologically, macrophages appear to accumulate in the sinusoidal and perisinusoidal spaces in PSC but not in primary biliary cirrhosis (PBC) and other biliary tract diseases. The accumulation is independent of necrosis, cholestasis, or neutrophil infiltration but whether the increased number of macrophages is a primary cause of PSC or secondary to chronic cholangitis remains to be determined [93].

Further complicating the interpretation of these types of studies are the high rates of gram-negative biliary isolates from patients with dominant stenosis. Compared to those without a dominant stenosis, these PSC patients have a higher load of bacteria and a shorter time to liver transplantation [94]. Other organisms postulated to be involved in the induction of the innate immune response in PSC include Chlamydia spp. and Helicobacter pylori. Ponsioen et al. found an elevated seroprevalence of Chlamydia-LPS antibodies in PSC patients compared to a matched control group. The lack of Chlamydia spp. in cultures of bile from these patients suggested that these findings were not due to active infection [95]. Amplification of 16S ribosomal RNA from explanted livers of 25 patients with PSC detected Helicobacter sequences in perihilar ductal and liver tissue of six of these patients. However, three of 31 control livers with non-biliary tract disease also demonstrated Helicobacter rRNA sequences [96]. Similarly, Boomkens et al. reported no significant difference between the incidence of Helicobacter DNA in liver tissue form PSC patients compared to controls [97]. In addition, there has not been any evidence that Helicobacter affects the histology of biliary epithelium [98].

\section{Liver T cells}

While the lymphocytic infiltrate of PSC has been repeatedly shown to be primarily $\mathrm{T}$ cells, the composition of T-cell subsets varies by study. A predominance of CD4+ T cells with a Th-1 phenotype [99] has been shown by some, while others have found a predominance of $\mathrm{CD} 8+\mathrm{T}$ cells $[100$, 101] or no difference in the $\mathrm{CD} 4 / \mathrm{CD} 8$ ratio compared to other liver diseases [102]. These inconsistencies may be explained by the distribution of T-cell subsets within the liver in which $\mathrm{CD} 4+\mathrm{T}$ cells predominate the portal infiltrate, while CD8 $+\mathrm{T}$ cells comprise the majority of the lobular infiltrate [103]. Thus, PSC patients with more significant lobular inflammation may display a greater percentage of CD8+ T cells.

There is some evidence that the $\mathrm{T}$ cells may have oligoclonal restriction. Probert et al. reported that $\mathrm{T}$ cells isolated from the common bile duct epithelium obtained during endoscopic retrograde cholangiography of two PSC patients had a large number of CD3+ CD43+ CD45RO+ lymphocytes [104]. Analysis of the variability of the T-cell receptor (TCR), specifically the complimentarity determining region 3 length and TCRV $\beta$ usage, suggested that the derived cell lines were oligoclonal. Consistent with these findings, Broome et al. demonstrated that the liver infiltrates of PSC patients more often stain positive for TCRV $\beta 3$ compared to those with PBC and healthy controls [105].

In addition to the $\alpha \beta$ T cells infiltrating the liver, there are increased proportions of $\gamma \delta+\mathrm{T}$ cells in PSC. The percentage of $\gamma \delta+\mathrm{T}$ cells in peripheral blood of PSC patients is greater than healthy controls and co-express IL-2 receptor and $\mathrm{CD} 45 \mathrm{RO}$ suggesting that they have an activated memory phenotype $[106,107]$. An increase in the absolute number and proportion of $\gamma \delta \mathrm{T}$ cells has also been reported in the portal area of PSC patients [106].

Integrins, chemokines, and chemokine receptors

Tissue-specific recruitment of lymphocytes to inflammation involves the coordinated recognition of "addressins" expressed by vascular endothelial cells by homing receptors on the lymphocyte along with interactions of chemokines and chemokine receptors. For example, lymphocytes activated by dendritic cells in gut-associated lymphatic tissue are programmed to express the $\alpha 4 \beta 7$ integrin and the CCR9 chemokine receptor. The ligand for $\alpha 4 \beta 7$ is the mucosal adressin cell adhesion molecule-1 (MAdCAM-1) which is specifically expressed on the intestinal endothelium and during inflammation on intestinal mucosa. The CCR9 ligand CCL25, which is also capable of activating $\alpha 4 \beta 7$, is expressed preferentially in the intestine as well. The combination of MAdCAM-1 and CCL25 is critical for the specific recruitment of $\alpha 4 \beta 7+\mathrm{CCR} 9+$ lymphocytes to the intestine. Similarly, homing to the skin involves interactions between cutaneous lymphocyte antigen with Eselectin and CCL17 with CCR4. However, recruitment of lymphocytes to the liver does not appear to involve a specific pairing of adhesion molecules and chemokines. Rather, multiple adhesion molecules and chemokines appear to 
recruit lymphocytes to the liver. Several of these molecules have been implicated in the pathogenesis of PSC, but their specificity to PSC as opposed to being generic in liver inflammation requires further exploration.

Most notably, MAdCAM-1 was initially thought to be confined to gut endothelium, but has since been shown to be expressed in the portal vein and sinusoidal endothelium in autoimmune-mediated liver disease. Grant et al. reported the presence of MAdCAM-1 staining in the portal veins of 11/16 PSC patients, 6/10 autoimmune hepatitis (AIH) patients and 3/11 PBC patients [36]. Dual-color immunofluorescence demonstrated the proximity of $\alpha 4 \beta 7 \mathrm{~T}$ cells to MAdCAM-1-positive vessels, and adhesion assays confirmed the functionality of the interaction. Somewhat surprisingly, however, the frequency of $\alpha_{\mathrm{E}} \beta 7+$, but not $\alpha 4 \beta 7+$ liver-infiltrating lymphocytes (LIL) was increased relative to peripheral blood in PSC. In the only other study of the expression of MAdCAM-1 in human liver diseases, Hillan et al. detected MAdCAM-1 associated with portal tract inflammation in chronic hepatitis $\mathrm{C}$ and $\mathrm{B}$ as well as PBC and PSC [108].

In contrast to $\alpha 4 \beta 7+$ LIL, CCR9+ LIL do appear to be specifically increased in PSC compared to PBC. Although the frequency of CCR9+ lymphocytes is not increased in peripheral blood, approximately $20 \%$ of LIL from PSC livers express CCR 9 compared to $<2 \%$ in normal livers or $\mathrm{PBC}$ [34]. This is in comparison to nearly $100 \%$ of lamina propria lymphocytes expressing CCR9+ in Crohn's disease. These CCR9+ LIL include CD8+ and CD4+ T cells, the former demonstrating a memory phenotype. Notably in apparent contradiction to their earlier work in which only $6 \%$ of CD3+ LIL expressed $\alpha 4 \beta 7$ [36], Eksteen et al. reported that $\alpha 4 \beta 7$ is co-expressed with CCR9. Nevertheless, the origin of these $\alpha 4 \beta 7+$ CCR9+ lymphocytes being the intestine is supported by the recent finding that liver dendritic cells and stellate cells were unable to imprint these homing markers on CD8+ T cells [32].

The CCR9 ligand CCL25 also appears to be specifically upregulated in PSC liver. Furthermore, CCR9+ LIL preferentially migrate to CCL25 rather than to CXCL12 or CCL5 and are triggered by CCL25 to bind immobilized MAdCAM-1 via $\alpha 4 \beta 7$.

Vascular adhesion protein-1 (VAP-1) is present on sinusoidal and vascular endothelium of most organs, including the liver with the greatest abundance found in high endothelial venules of peripheral lymph nodes. Neither bile ducts nor hepatocytes appear to express VAP-1 [109111]. However, it does not belong to the selectin, integrin, or immunoglobulin super families [112]. In addition to adhesion of lymphocytes to peripheral lymph node high endothelial venules [113], it promotes shear-dependent lymphocyte adhesion to and transmigration across hepatic sinusoidal endothelium in vitro $[109,110,114]$. Further- more, Lalor et al. reported that binding of benzylamine to VAP-1 in hepatic endothelial cells resulted in rapid activation of NF-KB. This led to expression of CXCL8, E-selectin, and ICAM-1 and upregulation of leukocyte adhesion [115]. Bonder et al. reported that Th1 cells use $\alpha 4 \beta 1$ and Th2 cells use VAP-1 to adhere to sinusoidal epithelium. This was in contrast to previous theories that leukocyte recruitment in the sinusoids was mediated by physical trapping rather than adhesion [116]. The lymphocyte ligand of VAP-1 has not been identified and its role in the homing of lymphocytes to the liver in PSC has not been established.

Integrin $\alpha \mathrm{V} \beta 6$ is expressed in large amounts on certain activated epithelia, mediating attachment to fibronectin and acting as a coreceptor for the activation of latent transforming growth factor (TGF)- $\beta 1$. In order to elucidate its role in liver fibrosis, Patsenker et al. studied $\alpha \mathrm{V} \beta 6$ function in rats after bile duct ligation and in $M d r 2-/-$ mice. $\alpha \mathrm{V} \beta 6$ was expressed in large amounts on proliferating bile duct epithelia in fibrosis. In addition, EMD527040, a $\alpha \mathrm{V} \beta 6$ antagonist, decreased bile ductular proliferation and peribiliary collagen deposition and downregulated fibrogenic genes while upregulating fibrolytic genes. It also reduced endogenous activation of TGF- $\beta 1$ [117]. In human liver, $\alpha \mathrm{V} \beta 6$ is absent in normal liver but is expressed on activated bile duct epithelia and transitional hepatocytes. In chronic hepatitis $C$, integrin $\beta 6$ mRNA increases with stage of fibrosis. Thus, $\alpha \mathrm{V} \beta 6$ does not appear to be a specific receptor targeting lymphocytes in PSC. Clearly, more research into the basic biology of lymphocyte homing to the liver and specificity of homing in PSC will expand our understanding of its pathogenesis tremendously.

Intestinal lymphocytes of PSC

If the liver inflammation of PSC is related to the aberrant homing of intestinal lymphocytes from IBD, perhaps the intestinal lymphocytes of the IBD associated with PSC differ phenotypically from IBD without PSC. A limited number of studies have examined intestinal lymphocytes from PSC patients and demonstrated that there are differences compared to IBD patients and healthy controls. PSC intestinal lymphocytes tend to have a lower frequency of IFN- $\gamma$ and IL-4-producing cells and have a blunted proliferative response to IL-2 compared to IBD lymphocytes [118, 119]. Increased numbers of intestinal NK cells in PSC-IBD compared to IBD have also been documented [118].

\section{Cytokines}

Th1 inflammatory mediators are the predominant type in PSC. Bo et al. reported significantly higher levels of TNF- $\alpha$ and IL-1 $\beta$ and lower concentrations of IL-2, IL-10, and 
IFN- $\gamma$ in supernatants of LIL from PSC patients compared with PBC, AIH, and normal controls [99]. Anti-TNF- $\alpha$ antibodies restored the previously diminished proliferative response. Impaired cytolytic activity of NK and T cells was also observed, and this was partially restored after treatment with TNF- $\alpha$ antibody treatment. The authors concluded that it is unlikely that the injury in PSC is mediated by direct cytotoxic effects because of the inability to detect normal cytotoxic activity of the LIL. Consistent with this are the results of a recently completed pilot study of the anti-TNF- $\alpha$ monoclonal antibody infliximab which showed no improvement in liver biochemistry or histology compared to placebo.

Aoki et al. used RNA microarray analysis of peripheral blood mononuclear cells to identify immune-related genes and pathways that are differentially expressed in PSC. They discovered that genes within the IL-2 receptor beta, IL-6, and MAP kinase pathways were expressed differently in PSC patients compared to controls. They also noted that individual genes, TNF- $\alpha$-induced protein 6 and membrane spanning 4-domains, subfamily A were upregulated in PSC while Mothers against decapentaplegic homolog 5 was downregulated. These findings are consistent with a systemic Th-1-mediated inflammatory response [120].

The effects of TNF- $\alpha$ and IFN- $\gamma$ may also have specific effects on bile acid secretion in PSC. Spirli et al. demonstrated that TNF- $\alpha$ and INF- $\gamma$ act synergistically to enhance nitric oxide production by increased nitric oxide synthase 2 (NOS2) gene and protein expression [121]. This in turn led to inhibition of cyclic-AMP dependent secretion by cholangiocytes. In contrast to $\mathrm{PBC}$ and chronic hepatitis C, PSC samples with advanced histologic stage had a significantly greater immunostaining of NOS2 in large and small bile ducts. The lack of increased staining in early stage PSC suggests that this change is in response to the underlying disease process, perhaps related to Th1-type responses to bouts of cholangitis.

\section{Humoral immune responses}

Autoantibodies are frequent in PSC but their pathologic significance remains unknown. Anti-neutrophil antibodies are often found in a perinuclear ( $\mathrm{p}$-ANCA) or atypical perinuclear pattern in approximately $80 \%$ of patients, but the diagnostic utility of this is somewhat limited because of the overlap with autoimmune hepatitis [122]. The atypical perinuclear pattern appears to be specific to PSC and AIH with staining of the nuclear periphery and multiple intranuclear foci. Both $\operatorname{IgG}$ and IgA classes of ANCA are prevalent in $\mathrm{AIH}$ and PSC; however, the atypical perinuclear staining pattern appears to be the predominant staining pattern for the IgG class in PSC. In contrast, the IgA class is found in an equal proportion of the atypical perinuclear pattern and the classical pattern. In patients with both IgG and IgA ANCA, IgA appears to be responsible for the classic p-ANCA staining while the IgG produces the atypical p-ANCA [123]. There is some preliminary evidence that the presence of p-ANCA may be able to be used as a prognostic indicator in PSC [124], although others have not been able to confirm this and the titer does not correlate with disease activity $[123,125]$.

The autoantigen to which both the classic and atypical pANCA in PSC react has yet to be identified. Orth et al. reported that catalase autoantibodies were present in $60 \%$ of their PSC cohort and alpha-enolase autoantibodies were present in $27 \%$ [126]. Catalase is an antioxidant that protects against cell damage from highly reactive oxygenderived free radicals. Inhibition of catalase function might lead to increased oxidative stress in PSC. Bactericidal/ permeability increasing (BPI) protein, an endotoxin-binding neutrophil leukocyte-granule protein that has antibacterial and anti-endotoxin properties, has also been suggested as a potential target of p-ANCA in PSC $[127,128]$. Stoffel et al. reported that BPI-ANCA was present in 36\% (13/36) of PSC patients compared to less than $10 \%$ of patients with ANCA-associated vasculitidies and disease controls [128]. They hypothesized that BPI-ANCA dampens the endotoxin-neutralizing ability of BPI leading to overexpression of bacterial antigenic stimuli. However, BPIANCA has also been found in cystic fibrosis, IBD, and vasculitis and is associated with higher inflammatory disease activity and greater organ damage [127].

More recently, it has been reported that atypical pANCA recognizes tubulin beta isoform 5 in human neutrophils and the bacterial cell division protein FtsZ which is present in almost all bacteria of the intestinal microflora [129, 130]. The authors suggest that this may reflect molecular mimicry in which autoantibodies triggered by a bacterial infection cross-react and inhibit normal immune cell functions [131]. Unfortunately, these results have only been published in preliminary form.

As mentioned above, there is evidence that BEC are targets of autoantibodies in PSC. Xu et al. reported that autoantibodies against surface antigens on BEC were found in a significantly greater percentage of PSC patients $(63.3 \%)$ compared to PBC (37\%) or AIH (16\%) patients or normal controls (8\%). Anti-BEC sera also caused BEC to increase expression of CD44 and production of IL-6 potentially leading to the recruitment of memory T cells via CD44 [132].

\section{Concluding remarks}

The etiopathogenesis of PSC remains enigmatic. Genetic susceptibility to the disease is clearly an important factor and as the specific genetic components are identified, better insights into the mechanisms of this disease will be 
understood. Although progress has been made into the recruitment of lymphocytes from the gut to the liver, why chronic inflammation and fibrosis occurs only in a subset of IBD patients remains to be defined. In addition, an important question remains as to whether this same process holds true for the growing percentage of PSC patients without IBD. The lack of an adequate animal model and the relative infrequency of the disease remain major obstacles to progress and will only be overcome with close collaboration and focused research into the immunopathogenesis of PSC.

Open Access This article is distributed under the terms of the Creative Commons Attribution Noncommercial License which permits any noncommercial use, distribution, and reproduction in any medium, provided the original author(s) and source are credited.

\section{References}

1. Chapman R, Cullen S (2008) Etiopathogenesis of primary sclerosing cholangitis. World J Gastroenterol 14:3350-3359. doi:10.3748/wjg. 14.3350

2. Aoki CA, Bowlus CL, Gershwin ME (2005) The immunobiology of primary sclerosing cholangitis. Autoimmun Rev 4:137143. doi:10.1016/j.autrev.2004.09.003

3. Saich R, Chapman R (2008) Primary sclerosing cholangitis, autoimmune hepatitis and overlap syndromes in inflammatory bowel disease. World J Gastroenterol 14:331-337. doi:10.3748/ wjg. 14.331

4. Karlsen TH, Schrumpf E, Boberg KM (2007) Genetic epidemiology of primary sclerosing cholangitis. World J Gastroenterol 13:5421-5431

5. Bambha K, Kim WR, Talwalkar J, Torgerson H, Benson JT, Therneau TM, Loftus EV Jr, Yawn BP, Dickson ER, Melton LJ 3 rd (2003) Incidence, clinical spectrum, and outcomes of primary sclerosing cholangitis in a United States community. Gastroenterology 125:1364-1369. doi:10.1016/j.gastro.2003.07.011

6. Kingham JG, Kochar N, Gravenor MB (2004) Incidence, clinical patterns, and outcomes of primary sclerosing cholangitis in South Wales, United Kingdom. Gastroenterology 126:19291930. doi:10.1053/j.gastro.2004.04.052

7. Boberg KM, Aadland E, Jahnsen J, Raknerud N, Stiris M, Bell H (1998) Incidence and prevalence of primary biliary cirrhosis, primary sclerosing cholangitis, and autoimmune hepatitis in a Norwegian population. Scand J Gastroenterol 33:99-103. doi:10.1080/00365529850166284

8. Kaplan GG, Laupland KB, Butzner D, Urbanski SJ, Lee SS (2007) The burden of large and small duct primary sclerosing cholangitis in adults and children: a population-based analysis. Am J Gastroenterol 102:1042-1049. doi:10.1111/j.1572-0241. 2007.01103.x

9. Card TR, Solaymani-Dodaran M, West J (2008) Incidence and mortality of primary sclerosing cholangitis in the UK: a population-based cohort study. J Hepatol 48:939-944. doi:10.1016/j.jhep. 2008.02.017

10. Hurlburt KJ, McMahon BJ, Deubner H, Hsu-Trawinski B, Williams JL, Kowdley KV (2002) Prevalence of autoimmune liver disease in Alaska Natives. Am J Gastroenterol 97:24022407. doi:10.1111/j.1572-0241.2002.06019.x
11. Kochhar R, Goenka MK, Das K, Nagi B, Bhasin DK, Chawla YK, Vaiphei K, Singh K, Dilawari JB (1996) Primary sclerosing cholangitis: an experience from India. J Gastroenterol Hepatol 11:429-433. doi:10.1111/j.1440-1746.1996.tb00286.x

12. Escorsell A, Pares A, Rodes J, Solis-Herruzo JA, Miras M, de la Morena E (1994) Epidemiology of primary sclerosing cholangitis in Spain. Spanish Association for the Study of the Liver. J Hepatol 21:787-791. doi:10.1016/S0168-8278(94)80240-8

13. Shorbagi A, Bayraktar Y (2008) Primary sclerosing cholangitiswhat is the difference between east and west? World J Gastroenterol 14:3974-3981. doi:10.3748/wjg.14.3974

14. Schrumpf E, Boberg KM (2001) Epidemiology of primary sclerosing cholangitis. Best Pract Res Clin Gastroenterol 15:553-562. doi:10.1053/bega.2001.0204

15. Tanaka A, Takamori Y, Toda G, Ohnishi S, Takikawa H (2008) Outcome and prognostic factors of 391 Japanese patients with primary sclerosing cholangitis. Liver Int 28:983-989

16. Takikawa H (2007) Characteristics of primary sclerosing cholangitis in Japan. Hepatol Res 37(Suppl 3):S470-S473. doi:10.1111/j.1872-034X.2007.00241.x

17. Wiesner RH, Grambsch PM, Dickson ER, Ludwig J, MacCarty RL, Hunter EB, Fleming TR, Fisher LD, Beaver SJ, LaRusso NF (1989) Primary sclerosing cholangitis: natural history, prognostic factors and survival analysis. Hepatology 10:430-436. doi:10.1002/hep.1840100406

18. Broome U, Olsson R, Loof L, Bodemar G, Hultcrantz R, Danielsson A, Prytz H, Sandberg-Gertzen H, Wallerstedt S, Lindberg G (1996) Natural history and prognostic factors in 305 Swedish patients with primary sclerosing cholangitis. Gut 38:610-615. doi:10.1136/gut.38.4.610

19. Schrumpf E, Abdelnoor M, Fausa O, Elgjo K, Jenssen E, Kolmannskog F (1994) Risk factors in primary sclerosing cholangitis. J Hepatol 21:1061-1066. doi:10.1016/S0168-8278 (05)80618-X

20. Farrant JM, Hayllar KM, Wilkinson ML, Karani J, Portmann BC, Westaby D, Williams R (1991) Natural history and prognostic variables in primary sclerosing cholangitis. Gastroenterology 100:1710-1717

21. Okolicsanyi L, Fabris L, Viaggi S, Carulli N, Podda M, Ricci G (1996) Primary sclerosing cholangitis: clinical presentation, natural history and prognostic variables: an Italian multicentre study. The Italian PSC Study Group. Eur J Gastroenterol Hepatol 8:685-691

22. Takikawa H, Takamori Y, Tanaka A, Kurihara H, Nakanuma Y (2004) Analysis of 388 cases of primary sclerosing cholangitis in Japan; presence of a subgroup without pancreatic involvement in older patients. Hepatol Res 29:153-159. doi:10.1016/j. hepres.2004.03.006

23. Ang TL, Fock KM, Ng TM, Teo EK, Chua TS, Tan JY (2002) Clinical profile of primary sclerosing cholangitis in Singapore. J Gastroenterol Hepatol 17:908-913. doi:10.1046/j.14401746.2002.02835.x

24. Loftus EV Jr, Harewood GC, Loftus CG, Tremaine WJ, Harmsen WS, Zinsmeister AR, Jewell DA, Sandborn WJ (2005) PSC-IBD: a unique form of inflammatory bowel disease associated with primary sclerosing cholangitis. Gut 54:91-96. doi:10.1136/gut.2004.046615

25. Himmel ME, Hardenberg G, Piccirillo CA, Steiner TS, Levings MK (2008) The role of T-regulatory cells and Toll-like receptors in the pathogenesis of human inflammatory bowel disease. Immunology 125:145-153. doi:10.1111/j.1365-2567.2008.02939.x

26. Hampe J, Franke A, Rosenstiel P, Till A, Teuber M, Huse K, Albrecht M, Mayr G, De La Vega FM, Briggs J, Gunther S, Prescott NJ, Onnie CM, Hasler R, Sipos B, Folsch UR, Lengauer T, Platzer M, Mathew CG, Krawczak M, Schreiber S (2007) A genome-wide association scan of nonsynonymous SNPs identi- 
fies a susceptibility variant for Crohn disease in ATG16L1. Nat Genet 39:207-211. doi:10.1038/ng1954

27. Ogura Y, Bonen DK, Inohara N, Nicolae DL, Chen FF, Ramos R, Britton H, Moran T, Karaliuskas R, Duerr RH, Achkar JP, Brant SR, Bayless TM, Kirschner BS, Hanauer SB, Nunez G, Cho JH (2001) A frameshift mutation in NOD2 associated with susceptibility to Crohn's disease. Nature 411:603-606. doi: $10.1038 / 35079114$

28. Hugot JP, Chamaillard M, Zouali H, Lesage S, Cezard JP, Belaiche J, Almer S, Tysk C, O’Morain CA, Gassull M, Binder V, Finkel Y, Cortot A, Modigliani R, Laurent-Puig P, GowerRousseau C, Macry J, Colombel JF, Sahbatou M, Thomas G (2001) Association of NOD2 leucine-rich repeat variants with susceptibility to Crohn's disease. Nature 411:599-603. doi: $10.1038 / 35079107$

29. Grant AJ, Lalor PF, Salmi M, Jalkanen S, Adams DH (2002) Homing of mucosal lymphocytes to the liver in the pathogenesis of hepatic complications of inflammatory bowel disease. Lancet 359:150-157. doi:10.1016/S0140-6736(02)07374-9

30. Vierling J (1998) Aetiopathogenesis of primary sclerosing cholangitis. In: Manns P, Stieihl A, Wiesner R (eds) Primary sclerosing cholangitis. Kluwer Academic, London, p 9

31. O'Mahony CA, Vierling JM (2006) Etiopathogenesis of primary sclerosing cholangitis. Semin Liver Dis 26:3-21. doi:10.1055/s2006-933559

32. Eksteen B, Mora JR, Haughton EL, Henderson NC, Lee-Turner L, Villablanca EJ, Curbishley SM, Aspinall AI, von Andrian UH, Adams DH (2009) Gut homing receptors on CD8 T-cells ARE retinoic acid dependent and not maintained by Liver dendritic or stellate cells. Gastroenterology (in press)

33. Eksteen B, Miles A, Curbishley SM, Tselepis C, Grant AJ, Walker LS, Adams DH (2006) Epithelial inflammation is associated with CCL28 production and the recruitment of regulatory T cells expressing CCR10. J Immunol 177:593-603

34. Eksteen B, Grant AJ, Miles A, Curbishley SM, Lalor PF, Hubscher SG, Briskin M, Salmon M, Adams DH (2004) Hepatic endothelial CCL25 mediates the recruitment of CCR9+ guthoming lymphocytes to the liver in primary sclerosing cholangitis. J Exp Med 200:1511-1517. doi:10.1084/jem.20041035

35. Grant AJ, Goddard S, Ahmed-Choudhury J, Reynolds G, Jackson DG, Briskin M, Wu L, Hubscher SG, Adams DH (2002) Hepatic expression of secondary lymphoid chemokine (CCL21) promotes the development of portal-associated lymphoid tissue in chronic inflammatory liver disease. Am J Pathol 160:1445-1455

36. Grant AJ, Lalor PF, Hubscher SG, Briskin M, Adams DH (2001) MAdCAM-1 expressed in chronic inflammatory liver disease supports mucosal lymphocyte adhesion to hepatic endothelium (MAdCAM-1 in chronic inflammatory liver disease). Hepatology 33:1065-1072. doi:10.1053/jhep.2001.24231

37. Kurkijarvi R, Adams DH, Leino R, Mottonen T, Jalkanen S, Salmi M (1998) Circulating form of human vascular adhesion protein-1 (VAP-1): increased serum levels in inflammatory liver diseases. J Immunol 161:1549-1557

38. Fickert P, Moustafa T, Trauner M (2007) Primary sclerosing cholangitis - the arteriosclerosis of the bile duct? Lipids Health Dis 6:3. doi:10.1186/1476-511X-6-3

39. Rosmorduc O, Hermelin B, Boelle PY, Poupon RE, Poupon R, Chazouilleres O (2004) ABCB4 gene mutations and primary sclerosing cholangitis. Gastroenterology 126:1220-1222. doi:10.1053/j.gastro.2004.02.042 author reply 1222-1223

40. Pauli-Magnus C, Kerb R, Fattinger K, Lang T, Anwald B, Kullak-Ublick GA, Beuers U, Meier PJ (2004) BSEP and MDR3 haplotype structure in healthy Caucasians, primary biliary cirrhosis and primary sclerosing cholangitis. Hepatology 39:779-791. doi:10.1002/hep.20159
41. Stiehl A, Rudolph G, Sauer P, Theilmann L (1995) Biliary secretion of bile acids and lipids in primary sclerosing cholangitis. Influence of cholestasis and effect of ursodeoxycholic acid treatment. J Hepatol 23:283-289

42. Vierling JM (2001) Animal models for primary sclerosing cholangitis. Best Pract Res Clin Gastroenterol 15:591-610. doi:10.1053/bega.2001.0207

43. Hobson CH, Butt TJ, Ferry DM, Hunter J, Chadwick VS, Broom MF (1988) Enterohepatic circulation of bacterial chemotactic peptide in rats with experimental colitis. Gastroenterology 94:1006-1013

44. Anderson RP, Butt TJ, Chadwick VS (1992) Hepatobiliary excretion of bacterial formyl-methionyl peptides in rat. Structure activity studies. Dig Dis Sci 37:248-256. doi:10.1007/ BF01308179

45. Hobson CH, Roberts EC, Broom MF, Mellor DM, Sherriff RM, Chadwick VS (1990) Radio-immunoassay for formyl methionyl leucyl phenylalanine. I. Development and application to assessment of chemotactic peptide production by enteric bacteria. J Gastroenterol Hepatol 5:32-37. doi:10.1111/j.1440-1746.1990. tb01765.x

46. Yamada S, Ishii M, Kisara N, Nagatomi R, Toyota T (1999) Macrophages are essential for lymphocyte infiltration in formyl peptide-induced cholangitis in rat liver. Liver 19:253-258. doi:10.1111/j.1478-3231.1999.tb00043.x

47. Yamada S, Ishii M, Liang LS, Yamamoto T, Toyota T (1994) Small duct cholangitis induced by N-formyl L-methionine Lleucine L-tyrosine in rats. J Gastroenterol 29:631-636. doi:10.1007/BF02365447

48. Lichtman SN, Sartor RB, Keku J, Schwab JH (1990) Hepatic inflammation in rats with experimental small intestinal bacterial overgrowth. Gastroenterology 98:414-423

49. Lichtman SN, Keku J, Schwab JH, Sartor RB (1991) Hepatic injury associated with small bowel bacterial overgrowth in rats is prevented by metronidazole and tetracycline. Gastroenterology 100:513-519

50. Lichtman SN, Okoruwa EE, Keku J, Schwab JH, Sartor RB (1992) Degradation of endogenous bacterial cell wall polymers by the muralytic enzyme mutanolysin prevents hepatobiliary injury in genetically susceptible rats with experimental intestinal bacterial overgrowth. J Clin Invest 90:1313-1322. doi:10.1172/ JCI115996

51. Bjornsson E, Cederborg A, Akvist A, Simren M, Stotzer PO, Bjarnason I (2005) Intestinal permeability and bacterial growth of the small bowel in patients with primary sclerosing cholangitis. Scand J Gastroenterol 40:1090-1094. doi:10.1080/ 00365520510023288

52. Scott JR, Fox-Robichaud AE (2002) Hepatic leukocyte recruitment in a model of acute colitis. Am J Physiol Gastrointest Liver Physiol 283:G561-G566

53. Mazzon E, Puzzolo D, Caputi AP, Cuzzocrea S (2002) Role of IL-10 in hepatocyte tight junction alteration in mouse model of experimental colitis. Mol Med 8:353-366

54. Lora L, Mazzon E, Martines D, Fries W, Muraca M, Martin A, d'Odorico A, Naccarato R, Citi S (1997) Hepatocyte tight-junctional permeability is increased in rat experimental colitis. Gastroenterology 113:1347-1354. doi:10.1053/gast.1997.v113.pm9322530

55. Numata Y, Tazuma S, Nishioka T, Ueno Y, Chayama K (2004) Immune response in mouse experimental cholangitis associated with colitis induced by dextran sulfate sodium. J Gastroenterol Hepatol 19:910-915. doi:10.1111/j.1440-1746.2003. 03333.X

56. Numata Y, Tazuma S, Ueno Y, Nishioka T, Hyogo H, Chayama K (2005) Therapeutic effect of repeated natural killer $\mathrm{T}$ cell stimulation in mouse cholangitis complicated by colitis. Dig Dis Sci 50:1844-1851. doi:10.1007/s10620-005-2949-2 
57. Blanco PG, Zaman MM, Junaidi O, Sheth S, Yantiss RK, Nasser IA, Freedman SD (2004) Induction of colitis in cftr-/- mice results in bile duct injury. Am J Physiol Gastrointest Liver Physiol 287:G491-G496. doi:10.1152/ajpgi.00452.2003

58. Rivera-Nieves J, Ho J, Bamias G, Ivashkina N, Ley K, Oppermann M, Cominelli F (2006) Antibody blockade of CCL25/CCR9 ameliorates early but not late chronic murine ileitis. Gastroenterology 131:1518-1529. doi:10.1053/j.gastro.2006.08.031

59. Fickert P, Fuchsbichler A, Wagner M, Zollner G, Kaser A, Tilg H, Krause R, Lammert F, Langner C, Zatloukal K, Marschall HU, Denk H, Trauner M (2004) Regurgitation of bile acids from leaky bile ducts causes sclerosing cholangitis in Mdr2 (Abcb4) knockout mice. Gastroenterology 127:261-274. doi:10.1053/j. gastro.2004.04.009

60. Weismuller TJ, Wedemeyer J, Kubicka S, Strassburg CP, Manns MP (2008) The challenges in primary sclerosing cholangitisaetiopathogenesis, autoimmunity, management and malignancy. J Hepatol 48(Suppl 1):S38-S57. doi:10.1016/S0168-8278(08) 60245-7

61. Bergquist A, Montgomery SM, Bahmanyar S, Olsson R, Danielsson A, Lindgren S, Prytz H, Hultcrantz R, Loof LA, Sandberg-Gertzen H, Almer S, Askling J, Ehlin A, Ekbom A (2008) Increased risk of primary sclerosing cholangitis and ulcerative colitis in first-degree relatives of patients with primary sclerosing cholangitis. Clin Gastroenterol Hepatol 6:939-943. doi:10.1016/j.cgh.2008.03.016

62. Schrumpf E, Fausa O, Forre O, Dobloug JH, Ritland S, Thorsby E (1982) HLA antigens and immunoregulatory $T$ cells in ulcerative colitis associated with hepatobiliary disease. Scand J Gastroenterol 17:187-191

63. Chapman RW, Varghese Z, Gaul R, Patel G, Kokinon N, Sherlock S (1983) Association of primary sclerosing cholangitis with HLA-B8. Gut 24:38-41. doi:10.1136/gut.24.1.38

64. Neri TM, Cavestro GM, Seghini P, Zanelli PF, Zanetti A, Savi M, Podda M, Zuin M, Colombo M, Floreani A, Rosina F, Bianchi Porro G, Strazzabosco M, Okolicsanyi L (2003) Novel association of HLA-haplotypes with primary sclerosing cholangitis (PSC) in a southern European population. Dig Liver Dis 35:571-576. doi:10.1016/S1590-8658(03)00274-3

65. Bittencourt PL, Palacios SA, Cancado EL, Carrilho FJ, Porta G, Kalil J, Goldberg AC (2002) Susceptibility to primary sclerosing cholangitis in Brazil is associated with HLA-DRB1*13 but not with tumour necrosis factor alpha-308 promoter polymorphism. Gut 51:609-610. doi:10.1136/gut.51.4.609

66. Jeffrey GP, Reed WD, Laurence BH, Shilkin KB (1990) Primary sclerosing cholangitis: clinical and immunopathological review of 21 cases. J Gastroenterol Hepatol 5:135-140. doi:10.1111/ j.1440-1746.1990.tb01818.x

67. Leidenius MH, Koskimies SA, Kellokumpu IH, Hockerstedt KA (1995) HLA antigens in ulcerative colitis and primary sclerosing cholangitis. APMIS 103:519-524

68. Prochazka EJ, Terasaki PI, Park MS, Goldstein LI, Busuttil RW (1990) Association of primary sclerosing cholangitis with HLADRw52a. N Engl J Med 322:1842-1844

69. Park MS (1991) Inability to attribute susceptibility to primary sclerosing cholangitis to specific amino acid positions of the HLA-DRw52a allele. N Engl J Med 325:1251-1252

70. Farrant JM, Doherty DG, Donaldson PT, Vaughan RW, Hayllar KM, Welsh KI, Eddleston AL, Williams R (1992) Amino acid substitutions at position 38 of the DR beta polypeptide confer susceptibility to and protection from primary sclerosing cholangitis. Hepatology 16:390-395. doi:10.1002/hep.1840160217

71. Spurkland A, Saarinen S, Boberg KM, Mitchell S, Broome U, Caballeria L, Ciusani E, Chapman R, Ercilla G, Fausa O, Knutsen I, Pares A, Rosina F, Olerup O, Thorsby E, Schrumpf E
(1999) HLA class II haplotypes in primary sclerosing cholangitis patients from five European populations. Tissue Antigens 53:459-469. doi:10.1034/j.1399-0039.1999.530502.x

72. Khakoo SI, Carrington M (2006) KIR and disease: a model system or system of models? Immunol Rev 214:186-201. doi:10.1111/j.1600-065X.2006.00459.X

73. Nelson GW, Martin MP, Gladman D, Wade J, Trowsdale J, Carrington M (2004) Cutting edge: heterozygote advantage in autoimmune disease: hierarchy of protection/susceptibility conferred by HLA and killer Ig-like receptor combinations in psoriatic arthritis. J Immunol 173:4273-4276

74. Martin MP, Gao X, Lee JH, Nelson GW, Detels R, Goedert JJ, Buchbinder S, Hoots K, Vlahov D, Trowsdale J, Wilson M, O'Brien SJ, Carrington M (2002) Epistatic interaction between KIR3DS1 and HLA-B delays the progression to AIDS. Nat Genet 31:429-434

75. Lopez-Vazquez A, Rodrigo L, Martinez-Borra J, Perez R, Rodriguez M, Fdez-Morera JL, Fuentes D, Rodriguez-Rodero S, Gonzaez S, Lopez-Larrea C (2005) Protective effect of the HLA-Bw4I80 epitope and the killer cell immunoglobulin-like receptor 3DS1 gene against the development of hepatocellular carcinoma in patients with hepatitis $\mathrm{C}$ virus infection. $\mathrm{J}$ Infect Dis 192:162-165. doi:10.1086/430351

76. Khakoo SI, Thio CL, Martin MP, Brooks CR, Gao X, Astemborski J, Cheng J, Goedert JJ, Vlahov D, Hilgartner M, Cox S, Little AM, Alexander GJ, Cramp ME, O'Brien SJ, Rosenberg WM, Thomas DL, Carrington M (2004) HLA and NK cell inhibitory receptor genes in resolving hepatitis $\mathrm{C}$ virus infection. Science 305:872-874. doi:10.1126/science. 1097670

77. Karlsen TH, Boberg KM, Olsson M, Sun JY, Senitzer D, Bergquist A, Schrumpf E, Thorsby E, Lie BA (2007) Particular genetic variants of ligands for natural killer cell receptors may contribute to the HLA associated risk of primary sclerosing cholangitis. J Hepatol 46:899-906. doi:10.1016/j.jhep. 2007.01.032

78. Norris S, Kondeatis E, Collins R, Satsangi J, Clare M, Chapman R, Stephens H, Harrison P, Vaughan R, Donaldson P (2001) Mapping MHC-encoded susceptibility and resistance in primary sclerosing cholangitis: the role of MICA polymorphism. Gastroenterology 120:1475-1482. doi:10.1053/gast.2001.24041

79. Wiencke K, Spurkland A, Schrumpf E, Boberg KM (2001) Primary sclerosing cholangitis is associated to an extended B8DR3 haplotype including particular MICA and MICB alleles. Hepatology 34:625-630

80. Wiencke K, Karlsen TH, Boberg KM, Thorsby E, Schrumpf E, Lie BA, Spurkland A (2007) Primary sclerosing cholangitis is associated with extended HLA-DR3 and HLA-DR6 haplotypes. Tissue Antigens 69:161-169. doi:10.1111/j.1399-0039.2006.00738.x

81. Karlsen TH, Boberg KM, Vatn M, Bergquist A, Hampe J, Schrumpf E, Thorsby E, Schreiber S, Lie BA (2007) Different HLA class II associations in ulcerative colitis patients with and without primary sclerosing cholangitis. Genes Immun 8:275278. doi:10.1038/sj.gene.6364377

82. Gaj P, Habior A, Mikula M, Ostrowski J (2008) Lack of evidence for association of primary sclerosing cholangitis and primary biliary cirrhosis with risk alleles for Crohn's disease in Polish patients. BMC Med Genet 9:81. doi:10.1186/1471-2156-9-81

83. Karlsen TH, Hampe J, Wiencke K, Schrumpf E, Thorsby E, Lie BA, Broome U, Schreiber S, Boberg KM (2007) Genetic polymorphisms associated with inflammatory bowel disease do not confer risk for primary sclerosing cholangitis. Am J Gastroenterol 102:115-121. doi:10.1111/j.1572-0241.2006.00928.x

84. Yang X, Cullen SN, Li JH, Chapman RW, Jewell DP (2004) Susceptibility to primary sclerosing cholangitis is associated with polymorphisms of intercellular adhesion molecule-1. J Hepatol 40:375-379. doi:10.1016/j.jhep.2003.11.009 
85. Bowlus CL, Karlsen TH, Broome U, Thorsby E, Vatn M, Schrumpf E, Lie BA, Boberg KM (2006) Analysis of MAdCAM-1 and ICAM-1 polymorphisms in 365 Scandinavian patients with primary sclerosing cholangitis. J Hepatol 45:704710. doi:10.1016/j.jhep.2006.03.012

86. Donaldson P, Agarwal K, Saarinen S, Strassbourg C, Craggs A, Harrison P, Hudson M, Broome U, Manns M (2000) Investigation of CCR5 Delta 32 deletion and FAS/APO-1 (CD95) single nucleotide polymorphisms in primary sclerosing cholangitis (PSC). Hepatology 32:174A

87. Satsangi J, Simmons J, Marshall S, Mitchell S, Chapman R, Welsh K, Jewell D (2000) CCR5 Delta 32 polymorphism in inflammatory bowel disease: further association with ulcerative colitis and with primary sclerosing cholangitis. Gastroenterology 118:A337. doi:10.1016/S0016-5085(00)70216-2

88. Eri R, Jonsson JR, Pandeya N, Purdie DM, Clouston AD, Martin N, Duffy D, Powell EE, Fawcett J, Florin TH, Radford-Smith GL (2004) CCR5-Delta32 mutation is strongly associated with primary sclerosing cholangitis. Genes Immun 5:444-450. doi: $10.1038 /$ sj.gene. 6364113

89. Henckaerts L, Fevery J, Van Steenbergen W, Verslype C, Yap P, Nevens F, Roskams T, Libbrecht L, Rutgeerts P, Vermeire S (2006) CC-type chemokine receptor 5-Delta32 mutation protects against primary sclerosing cholangitis. Inflamm Bowel Dis 12:272-277. doi:10.1097/01.MIB.0000209790.21737.28

90. Melum E, Karlsen TH, Broome U, Thorsby E, Schrumpf E, Boberg KM, Lie BA (2006) The 32-base pair deletion of the chemokine receptor 5 gene (CCR5-Delta32) is not associated with primary sclerosing cholangitis in 363 Scandinavian patients. Tissue Antigens 68:78-81. doi:10.1111/j.1399-0039.2006.00604.x

91. Seki E, Brenner DA (2008) Toll-like receptors and adaptor molecules in liver disease: update. Hepatology 48:322-335. doi:10.1002/hep.22306

92. Karrar A, Broome U, Sodergren T, Jaksch M, Bergquist A, Bjornstedt M, Sumitran-Holgersson S (2007) Biliary epithelial cell antibodies link adaptive and innate immune responses in primary sclerosing cholangitis. Gastroenterology 132:15041514. doi:10.1053/j.gastro.2007.01.039

93. Cameron RG, Blendis LM, Neuman MG (2001) Accumulation of macrophages in primary sclerosing cholangitis. Clin Biochem 34:195-201. doi:10.1016/S0009-9120(01)00215-6

94. Pohl J, Ring A, Stremmel W, Stiehl A (2006) The role of dominant stenoses in bacterial infections of bile ducts in primary sclerosing cholangitis. Eur J Gastroenterol Hepatol 18:69-74. doi:10.1097/00042737-200601000-00012

95. Ponsioen CY, Defoer J, Ten Kate FJ, Weverling GJ, Tytgat GN, Pannekoek Y, Wertheim-Dillen PM (2002) A survey of infectious agents as risk factors for primary sclerosing cholangitis: are Chlamydia species involved? Eur J Gastroenterol Hepatol 14:641-648. doi:10.1097/00042737200206000-00009

96. Krasinskas AM, Yao Y, Randhawa P, Dore MP, Sepulveda AR (2007) Helicobacter pylori may play a contributory role in the pathogenesis of primary sclerosing cholangitis. Dig Dis Sci 52:2265-2270. doi:10.1007/s10620-007-9803-7

97. Boomkens SY, de Rave S, Pot RG, Egberink HF, Penning LC, Rothuizen J, Zondervan PE, Kusters JG (2005) The role of Helicobacter spp. in the pathogenesis of primary biliary cirrhosis and primary sclerosing cholangitis. FEMS Immunol Med Microbiol 44:221-225. doi:10.1016/j.femsim.2004.11.002

98. Leong RW, Sung JJ (2002) Review article: Helicobacter species and hepatobiliary diseases. Aliment Pharmacol Ther 16:10371045. doi:10.1046/j.1365-2036.2002.01282.x

99. Bo X, Broome U, Remberger M, Sumitran-Holgersson S (2001) Tumour necrosis factor alpha impairs function of liver derived $\mathrm{T}$ lymphocytes and natural killer cells in patients with primary sclerosing cholangitis. Gut 49:131-141. doi:10.1136/gut. 49.1.131

100. Whiteside TL, Lasky S, Si L, Van Thiel DH (1985) Immunologic analysis of mononuclear cells in liver tissues and blood of patients with primary sclerosing cholangitis. Hepatology 5:468474. doi:10.1002/hep. 1840050321

101. Si L, Whiteside TL, Schade RR, Starzl TE, Van Thiel DH (1984) T-lymphocyte subsets in liver tissues of patients with primary biliary cirrhosis $(\mathrm{PBC})$, patients with primary sclerosing cholangitis (PSC), and normal controls. J Clin Immunol 4:262-272. doi:10.1007/BF00915293

102. Snook JA, Chapman RW, Sachdev GK, Heryet A, Kelly PM, Fleming KA, Jewell DP (1989) Peripheral blood and portal tract lymphocyte populations in primary sclerosing cholangitis. J Hepatol 9:36-41. doi:10.1016/0168-8278(89)90073-1

103. Hashimoto E, Lindor KD, Homburger HA, Dickson ER, Czaja AJ, Wiesner RH, Ludwig J (1993) Immunohistochemical characterization of hepatic lymphocytes in primary biliary cirrhosis in comparison with primary sclerosing cholangitis and autoimmune chronic active hepatitis. Mayo Clin Proc 68:1049-1055

104. Probert CS, Christ AD, Saubermann LJ, Turner JR, Chott A, Carr-Locke D, Balk SP, Blumberg RS (1997) Analysis of human common bile duct-associated T cells: evidence for oligoclonality, $\mathrm{T}$ cell clonal persistence, and epithelial cell recognition. $\mathrm{J}$ Immunol 158:1941-1948

105. Broome U, Grunewald J, Scheynius A, Olerup O, Hultcrantz R (1997) Preferential V beta3 usage by hepatic T lymphocytes in patients with primary sclerosing cholangitis. J Hepatol 26:527534. doi:10.1016/S0168-8278(97)80417-5

106. Martins EB, Graham AK, Chapman RW, Fleming KA (1996) Elevation of gamma delta $\mathrm{T}$ lymphocytes in peripheral blood and livers of patients with primary sclerosing cholangitis and other autoimmune liver diseases. Hepatology 23:988-993

107. Wen L, Peakman M, Mieli-Vergani G, Vergani D (1992) Elevation of activated gamma delta $\mathrm{T}$ cell receptor bearing $\mathrm{T}$ lymphocytes in patients with autoimmune chronic liver disease. Clin Exp Immunol 89:78-82

108. Hillan KJ, Hagler KE, MacSween RN, Ryan AM, Renz ME, Chiu HH, Ferrier RK, Bird GL, Dhillon AP, Ferrell LD, Fong S (1999) Expression of the mucosal vascular addressin, MAdCAM-1, in inflammatory liver disease. Liver 19:509-518. doi:10.1111/j.1478-3231.1999.tb00084.x

109. Yoong KF, McNab G, Hubscher SG, Adams DH (1998) Vascular adhesion protein-1 and ICAM-1 support the adhesion of tumorinfiltrating lymphocytes to tumor endothelium in human hepatocellular carcinoma. J Immunol 160:3978-3988

110. McNab G, Reeves JL, Salmi M, Hubscher S, Jalkanen S, Adams DH (1996) Vascular adhesion protein 1 mediates binding of $T$ cells to human hepatic endothelium. Gastroenterology 110:522 528. doi:10.1053/gast.1996.v110.pm8566600

111. Eksteen B, Miles AE, Grant AJ, Adams DH (2004) Lymphocyte homing in the pathogenesis of extra-intestinal manifestations of inflammatory bowel disease. Clin Med 4:173-180

112. Jalkanen S, Salmi M (2008) VAP-1 and CD73, endothelial cell surface enzymes in leukocyte extravasation. Arterioscler Thromb Vasc Biol 28:18-26. doi:10.1161/ATVBAHA.107. 153130

113. Salmi M, Tohka S, Berg EL, Butcher EC, Jalkanen S (1997) Vascular adhesion protein 1 (VAP-1) mediates lymphocyte subtype-specific, selectin-independent recognition of vascular endothelium in human lymph nodes. J Exp Med 186:589-600. doi:10.1084/jem.186.4.589

114. Lalor PF, Edwards S, McNab G, Salmi M, Jalkanen S, Adams DH (2002) Vascular adhesion protein-1 mediates adhesion and transmigration of lymphocytes on human hepatic endothelial cells. J Immunol 169:983-992 
115. Lalor PF, Sun PJ, Weston CJ, Martin-Santos A, Wakelam MJ, Adams DH (2007) Activation of vascular adhesion protein-1 on liver endothelium results in an NF-kappaB-dependent increase in lymphocyte adhesion. Hepatology 45:465-474. doi:10.1002/hep.21497

116. Bonder CS, Norman MU, Swain MG, Zbytnuik LD, Yamanouchi J, Santamaria P, Ajuebor M, Salmi M, Jalkanen S, Kubes P (2005) Rules of recruitment for Th1 and Th2 lymphocytes in inflamed liver: a role for alpha-4 integrin and vascular adhesion protein-1. Immunity 23:153-163. doi:10.1016/j.immuni.2005.06.007

117. Patsenker E, Popov Y, Stickel F, Jonczyk A, Goodman SL, Schuppan D (2008) Inhibition of integrin alphavbeta6 on cholangiocytes blocks transforming growth factor-beta activation and retards biliary fibrosis progression. Gastroenterology 135:660-670. doi:10.1053/j.gastro.2008.04.009

118. Silvain C, Zeevi A, Saidman S, Duquesnoy RJ, Van Thiel DH (1995) Phenotypic and functional characteristics of colonic lymphocytes isolated from patients with primary sclerosing cholangitis and inflammatory bowel disease. Hepatogastroenterology 42:250-258

119. Broome U, Hultcrantz R, Lefvert AK, Yi Q (1998) Cytokine production from colonic $\mathrm{T}$ cells in patients with ulcerative colitis with and without primary sclerosing cholangitis. Dis Colon Rectum 41:1543-1549. doi:10.1007/BF02237304

120. Aoki CA, Dawson K, Kenny TP, Gershwin ME, Bowlus CL (2006) Gene expression by PBMC in primary sclerosing cholangitis: evidence for dysregulation of immune mediated genes. Clin Dev Immunol 13:265-271. doi:10.1080/ 17402520600800085

121. Spirli C, Fabris L, Duner E, Fiorotto R, Ballardini G, Roskams T, Larusso NF, Sonzogni A, Okolicsanyi L, Strazzabosco M (2003) Cytokine-stimulated nitric oxide production inhibits adenylyl cyclase and cAMP-dependent secretion in cholangiocytes. Gastroenterology 124:737-753. doi:10.1053/gast.2003.50100

122. Washington MK (2007) Autoimmune liver disease: overlap and outliers. Mod Pathol 20(Suppl 1):S15-S30. doi:10.1038/ modpathol.3800684

123. Schwarze C, Terjung B, Lilienweiss P, Beuers U, Herzog V, Sauerbruch T, Spengler U (2003) IgA class antineutrophil cytoplasmic antibodies in primary sclerosing cholangitis and autoimmune hepatitis. Clin Exp Immunol 133:283-289. doi:10.1046/j.1365-2249.2003.02195.x
124. Pokorny CS, Norton ID, McCaughan GW, Selby WS (1994) Anti-neutrophil cytoplasmic antibody: a prognostic indicator in primary sclerosing cholangitis. J Gastroenterol Hepatol 9:40-44. doi:10.1111/j.1440-1746.1994.tb01214.x

125. Bansi D, Chapman R, Fleming K (1996) Antineutrophil cytoplasmic antibodies in chronic liver diseases: prevalence, titre, specificity and IgG subclass. J Hepatol 24:581-586. doi:10.1016/S0168-8278(96)80144-9

126. Orth T, Kellner R, Diekmann O, Faust J, Meyer zum Buschenfelde KH, Mayet WJ (1998) Identification and characterization of autoantibodies against catalase and alpha-enolase in patients with primary sclerosing cholangitis. Clin Exp Immunol 112:507-515. doi:10.1046/j.1365-2249.1998.00583.x

127. Schultz H, Weiss J, Carroll SF, Gross WL (2001) The endotoxinbinding bactericidal/permeability-increasing protein (BPI): a target antigen of autoantibodies. J Leukoc Biol 69:505-512

128. Stoffel MP, Csernok E, Herzberg C, Johnson T, Carroll SF, Gross WL (1996) Anti-neutrophil cytoplasmic antibodies (ANCA) directed against bactericidal/permeability increasing protein (BPI): a new seromarker for inflammatory bowel disease and associated disorders. Clin Exp Immunol 104:54-59. doi:10.1046/ j.1365-2249.1996.d01-654.x

129. Terjung B, Soehne J, Worman HJ, Sauerbruch T, Spengler U (2006) Molecular mimicry between target antigen of ANCA and microbial protein FtsZ in autoimmune liver disorders. Hepatology 44:229A-229A

130. Terjung B, Muennich M, Gottwein J, Soehne J, Worman HJ, Sauerbruch T, Spengler U (2005) Identification of myeloidspecific tubulin-beta isotype 5 as target antigen of antineutrophil cytoplasmic antibodies in autoimmune liver disorders. Hepatology 42:288A-288A

131. Terjung B, Spengler U (2009) Atypical p-ANCA in PSC and AIH: a hint toward a "leaky gut"? Clin Rev Allergy Immunol 36:40-51

132. Xu B, Broome U, Ericzon BG, Sumitran-Holgersson S (2002) High frequency of autoantibodies in patients with primary sclerosing cholangitis that bind biliary epithelial cells and induce expression of CD44 and production of interleukin 6. Gut 51:120-127. doi:10.1136/gut.51.1.120

133. Lichtman SN, Keku J, Clark RL, Schwab JH, Sartor RB (1991) Biliary tract disease in rats with experimental small bowel bacterial overgrowth. Hepatology 13:766-772. doi:10.1002/hep.1840130425 